\title{
MINI-TRIALS IN ALBERTA
}

\section{THE HONOURABLE W.K. MOORE}

The Alberta Court of Queen's Bench has been offering the mini-trial, a specialized dispute resolution process, to litigants and the bar for the last four years. The impetus for this move was the length and time often involved in litigation. The attraction of the mini-trial is that it is a method of expediting dispute resolution and that the costs associated with it are considerably less than those for a regular trial.

The author outlines the history of the mini-trial, explaining how it developed in the U.S. as a private dispute resolution mechanism. The Alberta minitrial is essentially an expanded pre-trial procedure. and is offered by the Court at no cost to participants. There is no rigid, formal procedure to the Alberta mini-trial, and its great strength is in fact flexibility and informality. The only requirement the Court has is that the actual parties must be present for the arguments and at the end of the mini-trial, when the judge gives his or her opinion.

The author outlines the key elements of the minitrial, as they have evolved 10 date, including the role of the judge and the nature of the actual process.

The mini-trial has been enormously successful at encouraging settlements, which have followed or resulted from the mini-trial in over 90 percent of cases. Additionally, both counsel and clients appear to be quite pleased with the process. Despite this success, however, it should be noted that the minitrial may not be appropriate in all cases. The author describes the types of cases to which the mini-trial both is and is not well-suited. He offers a case study, of a mini-trial over which he presided. This mini-trial was successful and led to a settlement. In closing, the author provides information to interested counsel and parties as to how and when they can access the mini-trial. The article closes with a recommendation that minitrials always be considered as an option in lawsuits.
Depuis quatre ans, la Cour du Banc de la Reine de l'Alberta offre le mini-procès, un processus spécialisé de résolution des différends destiné aux litigants et aux membres du barreau. Les problèmes liés à la durée des procès a conduit à cette initiative. Le mini-procès a l'avantage d'accélérer la résolution des différends et de coûter considérablement moins cher qu'un procès normal.

Faisant l'historique du mini-procès, l'auteur explique comment le mini-procès a vu le jour aux États-Unis en tant que mécanisme privé de résolution des conflits. Le mini-procès de style albertain est essentiellement une variante augmentée de la procédure préalable à l'instruction. Il est offert gratuitement par la Cour. Son point fort réside dans sa flexibilité et son absence de formalités rigides. La Cour exige seulement que les parties soient présentes aux plaidoyers et à la fin du mini-procès, quand le juge prend sa décision.

L'auteur propose une description chronologique des éléments clés du mini-procès, y compris le rôle du juge et la nature du processus en soi.

Le mini-procès réussit remarquablement d̀ promouvoir les règlements, qui suivent le miniprocès ou en résultent dans 90 pour 100 des cas. De phus, il semble convenir à la fois au barreau et à la clientèle. Malgré ce succès, notons que le miniprocès n'est pas à utiliser dans tous les cas. L'auteur décrit le type de causes auxquelles il convient ou non. Il offre l'étude de cas d'un miniprocès auquel il a présidé et qui a abouti à un règlement. Enfin, l'auteur explique comment et quand les membres du barreau et les parties peuvent obtenir un mini-procès. Il conclut en recommandant que le mini-procès soit toujours considéré comme une solution de rechange aux procès.

\section{TABLE OF CONTENTS}

I. INTRODUCTION . . . . . . . . . . . . . . . . 195

II. BACKGROUND/THE FIRST MINI-TRIAL $\ldots \ldots \ldots \ldots \ldots 197$

III. THE ALBERTA MINI-TRIAL $\ldots \ldots \ldots \ldots \ldots \ldots \ldots \ldots 198$

A. PURPOSE/OBJECT $\ldots \ldots \ldots \ldots \ldots \ldots \ldots \ldots$ 
B. FLEXIBLE/INFORMAL PROCESS $\ldots \ldots \ldots \ldots \ldots \ldots 199$

C. KEY ELEMENTS . . . . . . . . . . . . . . . . 199

D. THE MINI-TRIAL PROCESS $\ldots \ldots \ldots \ldots \ldots \ldots \ldots 200$

IV. SUCCESS OF THE MINI-TRIAL $\ldots \ldots \ldots \ldots \ldots \ldots \ldots 202$

V. LIMITATIONS OF THE MINI-TRIAL PROCESS $\ldots \ldots \ldots \ldots 203$

VI. AN EXPERIENCE WITH THE

MINI-TRIAL PROCESS . . . . . . . . . . . . . 204

VII. HOW AND WHEN DOES ONE INITIATE

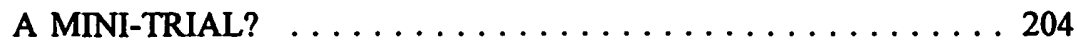

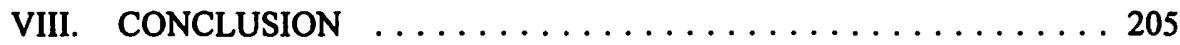

\section{INTRODUCTION}

For some time now, the Court of Queen's Bench of Alberta (the "Court"), both in Calgary and in Edmonton, has been offering a rather specialized service to the bar and to litigants in an effort to facilitate and expedite the settlement of disputes. Approximately four years ago, the Court, in consultation with the Alberta bar, and later with the Alberta Law Reform Institute, investigated and embarked upon a new process known as the "mini-trial."

"The provision of effective dispute resolution, both within and outside the judicial system, is a matter of considerable current interest and pursuit in Canada." ' This interest is derived, in part, from a dissatisfaction with the ability of the present process to resolve disputes and has resulted in a great deal of experimentation with an aim to improve the process, including "innovative dispute resolution methods, new models of dispute resolution, and variations and combinations of these methods and models."2

In Alberta, the development of the mini-trial evolved from the Court's concern that the litigation process was becoming far too lengthy and costly. Members of the legal profession were also anxious to find ways and means to dispose of contentious matters without the need for a full-blown trial. Therefore, in addition to a number of other measures introduced by the Court in an effort to make the trial system more efficient and effective, including measures to reduce delay associated with long trials, ${ }^{3}$ mandatory pre-trial conferences in certain instances ${ }^{4}$ and the introduction of case

$1 \quad$ Alberta Law Reform Institute, Dispute Resolution: A Directory of Methods, Projects and Resources (Research Paper No. 19) (Edmonton: Alberta Law Reform Institute, 1990) at 1 [hereinafter ALRI Research Paper No. 19].

2 Alberta Law Reform Institute, Civil Litigation: The Judicial Mini-Trial (Dispute Resolution Special Series, Discussion Paper No. I) (Edmonton: Alberta Law Reform Institute, 1993) at 1 [hereinafter ALRI Discussion Paper No. l].

3 The Court of Queen's Bench has established a committee, chaired by Madam Justice Bielby, to develop a Practice Note dealing with very long trials.

$4 \quad$ See Civil Practice Note 3 (Pre-Trial Conferences), issued 1 April 1995 and substituted for Civil Practice Note " $\mathrm{C}^{\text {" }}$ (Case Procedure Conferences), approved by the Court of Queen's Bench of Alberta, 28 May 1994, in Alberta Rules of Court, Schedules, Practice Notes 1995 (Edmonton: Juriliber) at 2-29. 
management of files, ${ }^{5}$ the Court has launched a mini-trial process. This endeavour has proven to be highly successful in Alberta.

The mini-trial is essentially an alternative method of dispute resolution or, as it is more commonly known, "ADR." ADR encompasses a wide variety of methods by which disputes are resolved and typically includes such methods as negotiation, mediation and arbitration. ADR embraces processes that are "truly alternative to the existing judicial system" but also includes "processes that modify or improve upon practices and procedures currently in use within the existing court system." ${ }^{6}$ All ADR techniques have been described as having the following fundamental characteristics:

1. An independent and impartial skilled neutral [who] assists the disputants to resolve their disputes;

2. The process is entirely voluntary;

3. The process is entirely confidential; [and]

4. The process is flexible and is controlled by the disputants themselves. ${ }^{7}$

As this article will demonstrate, these fundamental characteristics are all evident in the mini-trial process adopted in Alberta. Accordingly, depending upon the particular procedure employed in a given instance, the mini-trial process - as a voluntary dispute resolution technique - may resemble either mediation or adjudication or a blend thereof, or will resemble either a negotiated settlement or a non-binding arbitration. Unlike the classic form of arbitration, there is no final and binding result in the Alberta mini-trial process.

As with other ADR procedures, the object of the mini-trial is to "permit both parties to see how their cases will play before a [judge], without the formality, inconvenience, publicity, or irrevocability of an actual courtroom trial."

Within the context of this article, the term "mini-trial" refers to a settlement technique, introduced within the civil litigation system, to expedite the resolution of a dispute.' In this sense, the mini-trial may be considered to be either an "advanced

As of February 28, 1995, there were 450 actions being case-managed in Alberta.

ALRI Research Paper No. 19, supra note 1 at 1.

R.J. Everard, "Maximizing Dispute Resolution Alternatives: The Barrister's Perspective" in Legal Education Society of Alberta, Effective Dispute Resolution (Calgary \& Edmonton, Legal Education Society of Alberta, 1991) 83 at 85, with reference to B.J. Thompson, Q.C., "There Must Be A Better Way" (1989) 32 C.L.R. 74 at 74-75.

Hon. E.F. Lynch et al., California Negotiation and Settlement Handbook for Judges and Attorneys (San Francisco: Bancroft-Whitney Law Publishers, 1991) c. 7 at 44.

It has been suggested that the word "mini-trial" has at least three meanings: (1) a private mini-trial; (2) a judicial mini-trial; and (3) the separate trial of an issue [i.e. within the context, for instance, of Rules 220 and 232 of the Alberta Rules of Court] (ALRI Discussion Paper No. l, supra note 2 at $1-5)$. 
negotiation technique" or an "expedited litigation." 10 Clearly, if a settlement is achieved, the resolution of the litigation will have been expedited. Short of settlement, however, the mini-trial process may help to define, clarify, narrow and eliminate some or many of the issues, and thereby shorten the length of the trial which ultimately takes place. In any event, the simple exchange of information between the parties can be an aid to settlement discussions. Certainly, the costs associated with the mini-trial process are considerably less than those associated with a lengthy trial. Furthermore, even if the mini-trial process does not result in a settlement and litigation does ensue, these costs may not be entirely wasted, in that most of the preparation for the mini-trial can likely still be used in preparation for the trial.

\section{BACKGROUND/THE FIRST MINI-TRIAL}

As noted above, the mini-trial is essentially a dispute settlement or resolution technique. It is noteworthy that "the momentum for alternative dispute resolution in North America originated in the United States, where the outcry against the adversary nature of court proceedings and dissatisfaction with the judicial management of disputes has been loudly voiced." 11 The mini-trial process, therefore, was first developed as a "private mini-trial" in a very difficult and complex patent infringement case in the United States in 1977: the "Telecredit-TRW case."12 In that instance, the mini-trial was designed as an alternate vehicle for conflict resolution outside of the judicial process and without judicial intervention. In a nutshell, a "mini-trial" agreement was entered into by the parties and a format was established which provided for an information exchange and summary presentations by the parties to the executives of the business interests involved in the litigation who were then, as a result, able to work out a settlement.

At the time the parties in the Telecredit-TRW case decided to pursue a mini-trial approach, the proceeding was still in the discovery stage and hundreds of thousands of dollars in legal fees had been expended. ${ }^{13}$ Binding arbitration was unacceptable to the parties for a number of reasons and the traditional settlement negotiations had been unproductive. The procedure ultimately adopted by the parties, therefore, "consisted of a non-binding two-day information exchange between top corporate management and before a neutral adviser who was jointly selected."14 Although the entire proceeding took several months to organize, it took only a few days to present.

At the information exchange portion of the mini-trial, each side had an opportunity to present its best case on the issues in dispute to the management representatives of both companies. The mini-trial agreement [entered into by the parties] suspended the formal rules of evidence and permitted the parties to determine for themselves what evidence and argument [they wished] to present. ${ }^{\text {is }}$

10 E.D. Green, "Growth of the Mini-Trial" (1982) 9:1 Litigation 12 at 12.

" ALRI Research Paper No. 19, supra note 1 at 7.

$12 \quad$ M.F. Hoellering, "The Mini-Trial" (December 1982) 37:4 Arb. J. 48 at 50.

$13 \quad$ Ibid.

14 Green, supra note 10 at 13.

15 lbid. 
It is said that the information exchange, even at so late a stage in the proceedings, "provided the parties with new insights into the dispute ... saved them untold additional legal costs, and relieved both managements of the disruptions connected with the continued involvement in a high-risk law suit."16 Although no coercive tactics were employed, within one half-hour after the conclusion of the mini-trial proceeding, "the parties reached a settlement in principle of a long and bitterly fought law suit."17 As a result of the mini-trial process, the dispute was amicably resolved, and according to one source, "each side walked away, believers in the process as well as the result." 18

Since that time, the use of this type of mini-trial process has been extended to other private disputes in the United States and elsewhere, particularly in the commercial area. It has been utilized, for example, in cases involving breach of contract, products liability, insurance, government contracts and construction matters, and it has also been successfully applied in labour disputes and wrongful dismissal claims.

\section{THE ALBERTA MINI-TRIAL}

\section{A. PURPOSE/OBJECT}

The term "mini-trial" may be somewhat of a misnomer in that the process is not really a trial at all. Instead, as discussed above, it is a relatively formalized structure for settlement negotiation. The mini-trial process is premised on the belief, which has largely proven to be correct, that the structured presentation of evidence and arguments, on behalf of the parties before a judge, enables the parties to settle the dispute themselves on the basis of the non-binding opinion expressed by the judge at the conclusion of the process.

The aim of the mini-trial process is to facilitate prompt, cost-effective resolution of civil cases and generally those cases involving mixed questions of fact and law. The process, accordingly, is designed to:

1. Bring the parties together in the presence of a judge;

2. Enable the parties, through their counsel, to put forward their views on the issues;

3. Obtain, at the conclusion of argument, a non-binding opinion as to what the judge believes will happen at trial;

4. Promote or facilitate settlement discussions; and

5. Save the costs of a trial and reduce the lengthy time expended in litigation. 
The mini-trial is essentially an expanded pre-trial procedure.

\section{B. FLEXIBLE/INFORMAL PROCESS}

In Alberta, the mini-trial is a service offered by the Court - without cost - to the lawyers who request the service. Although use of the process is certainly encouraged in appropriate circumstances, there is no formal requirement that a mini-trial be conducted. This judicial assistance, therefore, lies outside the ordinary court process. It is not a "step in the action." The Court acknowledges the fact that mini-trials or any other form of judicial assistance outside of the ordinary court process is not at the present time sanctioned by the Alberta Rules of Court and thus depends upon the consent of the parties. Participation, therefore, is voluntary. In fact, one could go so far as to suggest that the process is only useful where both parties are "committed to resolving the dispute with a minimum of expense, delay, and disruption." 19

In Alberta, the Court has not formalized rules relating to how the mini-trial should take place. It is simply suggested that the lawyers who are representing parties who would like to dispose of the matter quickly and without the need for a costly trial, meet with a judge - in advance - to determine how the judge and the lawyers together would prefer to handle the matter. Flexibility is the most important characteristic of the Court's mini-trial process, in that it allows the parties to design a process to accommodate the requirements of each particular case. In fact, the singular advantage of the mini-trial procedures that have been followed in Edmonton and Calgary to date is simply that they have been conducted on a very informal and flexible basis.

The only requirement that the Court has made is that the parties must have their clients present when the arguments are presented and when the judge gives the opinion at the end of the arguments.

\section{KEY ELEMENTS}

Although the mini-trial process adopted in Alberta is a flexible process, through experimentation and adaptation to particular circumstances, the following "key elements" or guidelines have been identified in the mini-trials conducted to date:

1. All counsel must agree to participate in the mini-trial process;

2. The clients must be present while the lawyers are presenting their arguments to the judge and when the judge gives the opinion at the end of the arguments;

3. Neither the judge nor counsel are gowned during the mini-trial process; 
4. An Agreed Statement of Facts, if possible, should be prepared, and copies of expert reports, medical reports and authorities should be attached under separate dividers;

5. No costs are assessed at a mini-trial;

6. No evidence is to be adduced during a mini-trial - just argument based upon facts that are agreed upon or facts substantially agreed upon. Short written briefs of argument may be requested;

7. Evidence from Examinations for Discovery may be referred to at a mini-trial;

8. Counsel desirous of arranging a mini-trial date should initially contact the Trial Coordinator relative to a tentative date for the mini-trial and then endeavour to make an early appointment with the mini-trial judge assigned to that time frame. At that meeting, the mini-trial judge can assess whether or not a minitrial is appropriate and, if so, then confirm the date for the mini-trial, including the time to deliver briefs, if necessary;

9. It is to be made clear at the outset that the non-binding opinion of the judge rendered at the conclusion of the mini-trial is strictly confidential. The minitrial judge will not discuss the opinion given at the mini-trial with anyone else on the bench.

These elements are commonly present in most mini-trials, but excluding element number two, they are not intended to be rigidly and strictly adhered to and, as the process develops, will be subject to further evolution and refinement. In this way, the flexibility inherent in the mini-trial process utilized to date enables each of the elements to be tailored to achieve the best fit for the dispute at issue.

\section{THE MINI-TRIAL PROCESS}

Confidentiality is an important element of the process. The confidentiality of the mini-trial is protected by the assurance that the judge who conducts the mini-trial will not be the trial judge and will not discuss the opinion rendered at the conclusion of the mini-trial with anyone else on the bench. In Alberta, this understanding is an established part of the mini-trial process and is maintained by the cooperation, as a matter of policy, of the Chief Justice and the Associate Chief Justice, who assign the cases.

Ordinarily, but not necessarily, the judge who is assigned to or agrees to hear a minitrial will:

(a) when the mini-trial commences, explain the procedure that will be followed;

(b) ask counsel to provide summaries of the testimony that witnesses would give at trial and of the written materials that would be entered as exhibits; 
(c) take notes and ask questions for clarification as the presentations unfold;

(d) refer to examination for discovery transcripts and expert reports that have been exchanged;

(e) examine exhibits;

(f) [on occasion, by agreement] give the clients an opportunity to speak;

(g) invite counsel to present closing argument similar to the argument that would be presented at the end of the trial;

(h) before rendering an opinion, verify with all sides that the mini-trial judge knows as much about the issues as the trial judge would after a full trial hearing;

(i) point out that both sides are free to accept or reject any of the judge's conclusions;

(j) emphasize to the litigants that:

(i) enormous expense is involved in going to trial - the expense includes the cost of their own lawyer and the potential costs they may have to pay to the other side if they lose,

(ii) trial is a stressful process where pressure may be put on them,

(iii) the lawyers may encounter difficulties with their factual evidence at trial,

(iv) going to trial gives no guarantee of success, and

(v) judges are not infallible and are sometimes reversed on appeal;

(k) encourage the parties to negotiate a settlement within a reasonable time, on the basis of what they heard at the mini-trial; and

(I) invite counsel to let the judge know the outcome. ${ }^{20}$

While the parties to a mini-trial have the use of a courtroom, there is no court reporter present and a clerk is present only to keep track of exhibits. Furthermore, the proceeding is conducted in such a way so as to ensure that there is no intense adversarial atmosphere. The judge's opinion rendered at the conclusion of the process is not binding. There is also no appeal.

No pressure is exerted upon any of the parties during a mini-trial. As stated previously, however, it is very important that the client be present when the judge renders the opinion. The judge generally makes a special point to look directly at the clients or the parties when delivering the opinion. In this way, when telling the parties what the judge believes will happen when the matter proceeds to trial, the clients will feel that they are receiving the personal advice of an experienced judge. 


\section{SUCCESS OF THE MINI-TRIAL}

The mini-trial has been enormously successful in Alberta. At the end of the process, the lawyers are invited to advise the judge within a reasonable period of time whether they have been able to conclude a settlement. The information which has been provided to the Court to date suggests that where a mini-trial has been conducted, in approximately 90 percent of the cases or higher, the parties have been able to reach a settlement along the lines suggested by the judge or on the basis of something very similar to that suggested by the judge.

The feedback received from participants has been very positive. Counsel have advised that the opening remarks by the judge at the outset of the process, which explained the purpose and nature of the mini-trial as well as the costs and risks associated with a full trial, were very useful and instructive to their clients. It appears to be the consensus that attendance by the clients is essential. In this way, the clients are able not only to observe a form of the trial process in the "mini-trial" setting, but also, in some situations, they are able to play a role in the process.

According to the information conveyed by several lawyers, it appears that an added bonus of the process, which had not originally been contemplated, is that their clients had accepted settlement because they had heard it from a judge and because they had an opportunity to express to a judge, through counsel, what was troubling them. Counsel have advised that in some situations there was absolutely no doubt that the judge's opinion arising out of the mini-trial was the key factor in bringing about a settlement. Both counsel and their clients seem to hold the opinion that the opportunity to state the case in open court, in the presence of the opposing party and its counsel, is a very important element of the mini-trial process. Where the presiding judge also calls upon the clients to make submissions on their own behalf, clients are further assured that they are "having their day in court."

Both counsel and their clients have indicated that they appreciate the informality and lack of pressure and stress associated with the mini-trial process. In at least one instance, a client, who was very anxious about the prospect of a trial, found the informal procedure to be very useful and was happy to be able to obtain an opinion from a judge without suffering the stress of an actual trial.

We have often been advised that the opinion provided by the judge was the basis and the impetus for constructive settlement negotiations which ultimately culminated in the matter being resolved amicably and the business relationship of the parties being maintained or restored. The net result of the judge's opinion may simply be to cause litigants to view their positions in a more realistic light. For instance, in some circumstances, it may assist plaintiffs to lower unrealistic expectations or, in other circumstances, it may alert defendants to the fact that they could potentially lose the case and, in addition, face cost consequences. The net effect as well may simply be to force parties to put their minds forward to the upcoming trial and the possibility of settlement at a much earlier point in the process. It is axiomatic that any procedure which requires counsel to prepare well in advance will in turn encourage settlement. 
In the end, those involved in the process to date seem to be in agreement that, certainly when successful, the mini-trial is an economical and speedy way to have an action determined and, in any event, the time spent preparing for the mini-trial is very useful. In short, the mini-trial has been of particular and significant assistance in the settlement of disputes in many cases.

\section{LIMITATIONS OF THE MINI-TRIAL PROCESS}

Despite the tremendous success experienced in Alberta, It is recognized that this process may not be suitable for each and every lawsuit. For instance, cases which do not lend themselves very well to the process are those where there is conflicting evidence or where everything turns on the credibility of a witness. It is fairly difficult to assess credibility in a mini-trial setting. Even where the facts are not completely agreed upon, the mini-trial process can nevertheless be effective in those situations where a judge may be able to couch an opinion based upon the facts turning out one way or another.

Mini-trials will generally be successful in the same types of situations where mediation would also be successful. However, where cases involve pure questions of law, e.g. constitutional law questions, or where there are conflicting lines of authorities and the law is not settled or clear, the mini-trial may be of limited value. Both small and large disputes may be appropriate for the mini-trial process. Multi-party actions have also been settled successfully as a result of a mini-trial. It has been suggested that where the factual disputes are technical ones and promise a battle of experts, a minitrial should especially be considered and that one "should at least consider a mini-trial in every case." 21

In appropriate circumstances, the mini-trial may provide a "win/win" situation for all concerned. As Mr. Justice Miller has noted, ${ }^{22}$ from the Court's point of view, it may be a much better use of Court time to spend a half day on a mini-trial than to tie up a Court for three or four days of evidence. From the client's point of view, the matter is resolved quickly and they feel that they have "had their day in court." From the lawyer's point of view, the file of that particular case may now be closed and they may move on to the next case.

The procedure has been used successfully to facilitate the settlement of many complex cases in Alberta. Some of the cases have involved the interpretation of oil and gas contracts and various disputes between oil and gas companies. As well, personal injury cases involving the assessment of damages, matrimonial cases, construction cases, land disputes and many others have been the subject of a great many successful mini-trials. It has been suggested that wrongful dismissal suits are particularly amenable to resolution in the mini-trial process. 


\section{AN EXPERIENCE WITH THE MINI-TRIAL PROCESS}

Approximately three years ago, I conducted a mini-trial in a matter involving the City of Calgary and several defendants. The case related to the construction of the south leg of the light rail transportation ("L.R.T.") system in the City of Calgary. The issue to be resolved at the mini-trial was determining the method of calculating damages that the trial judge would probably follow and, perhaps, an assessment of the measure of damages that might be recoverable by the City. There is no doubt that if the matter had proceeded to trial, it would have involved an estimated three to four months of trial time and hundreds of thousands of dollars in legal fees and other costs.

Several lawyers were involved in the mini-trial; one representing the City of Calgary and five other lawyers representing the various defendants and third parties. An agreed summary of the facts was introduced at the commencement of the mini-trial. Each of the four lawyers were then given an opportunity to separately present argument. They each outlined the argument they would be mounting and which, indeed, would be the argument that would be presented to the trial judge at the conclusion of a trial. The argument, of course, included their assessment of how the evidence would unfold at trial and included the applicable legal authorities and other references.

The mini-trial took three days and, at the conclusion, I gave an opinion as to what I thought would happen at trial. The opinion which I prepared was read to counsel in the presence of the parties. In that opinion, I indicated that the state of the art evidence relating to the construction of the L.R.T. system would differ substantially between the initial work and the work carried out several years later to remedy deficiencies. I pointed out that the trial would likely consume several weeks of evidence. I also gave an estimate of what I thought would be involved in the way of damages. I was subsequently informed that the case had been settled within approximately two weeks following the mini-trial.

\section{HOW AND WHEN DOES ONE INITIATE A MINI-TRIAL?}

A request for a mini-trial may be made by one of the parties through counsel. A judge may also suggest that a mini-trial would be appropriate in a given circumstance.

The lawyers approach either the Chief Justice in Calgary or the Associate Chief Justice in Edmonton, or the respective Trial Coordinators in either city, to request a mini-trial. At least one week each month has been set aside and a judge is assigned to hear mini-trials. In each city, approximately eight judges have expressed an interest in, and are available to conduct, mini-trials.

Mini-trials have been conducted at various points, both early and late, in a proceeding. Often the request is made after discoveries have been conducted and even after the Certificate of Readiness has been filed. If the mini-trial is initiated after discoveries, counsel will then have an opportunity to refer to sworn testimony in the mini-trial process. Nevertheless, it is apparent that if the process is initiated earlier (and 
if ultimately proven to be successful), then the dispute may be resolved more quickly, more efficiently and in a less costly manner.

It is clear, however, that the facts and issues must be sufficiently developed to permit a meaningful analysis of the dispute and, regardless of when the mini-trial is initiated, successful preparation for the mini-trial will generally involve a full and complete exchange of information in advance. The United States Army Corps of Engineers has launched a very successful mini-trial program and its counsel suggest that "experience has shown that the best time to consider the mini-trial is early in [the discovery process], since the facts and issues have been somewhat developed but many of the costs of litigation have not yet been incurred." ${ }^{23}$ "The most important criterion in case selection is probably that the parties must want to resolve the dispute. Typically, it is not an all-or-nothing proposition. The parties must be committed to resolving the dispute with a minimum of expense, delay, and disruption. ${ }^{124}$

\section{CONCLUSION}

Experience to date suggests that the mini-trial has become a very important element in litigation and dispute resolution in Alberta. Although the mini-trial is not a formalized "step in an action" in this province, given the very high success rate associated with the mini-trial process, it is suggested that parties should always consider utilizing the process, particularly where lengthy and complex litigation is anticipated. The Court of Queen's Bench of Alberta will continue to make this service available to litigants, and counsel are urged to seriously consider this option as a matter of course. It is clearly important, however, that all parties must agree to participate, as settlement is unlikely to follow if one or more counsel or their clients lack enthusiasm for the mini-trial process. When the parties are committed, however, the mini-trial process can be a rewarding and satisfying experience for everyone involved, and can deliver an enormous savings in legal fees, court costs and time. 